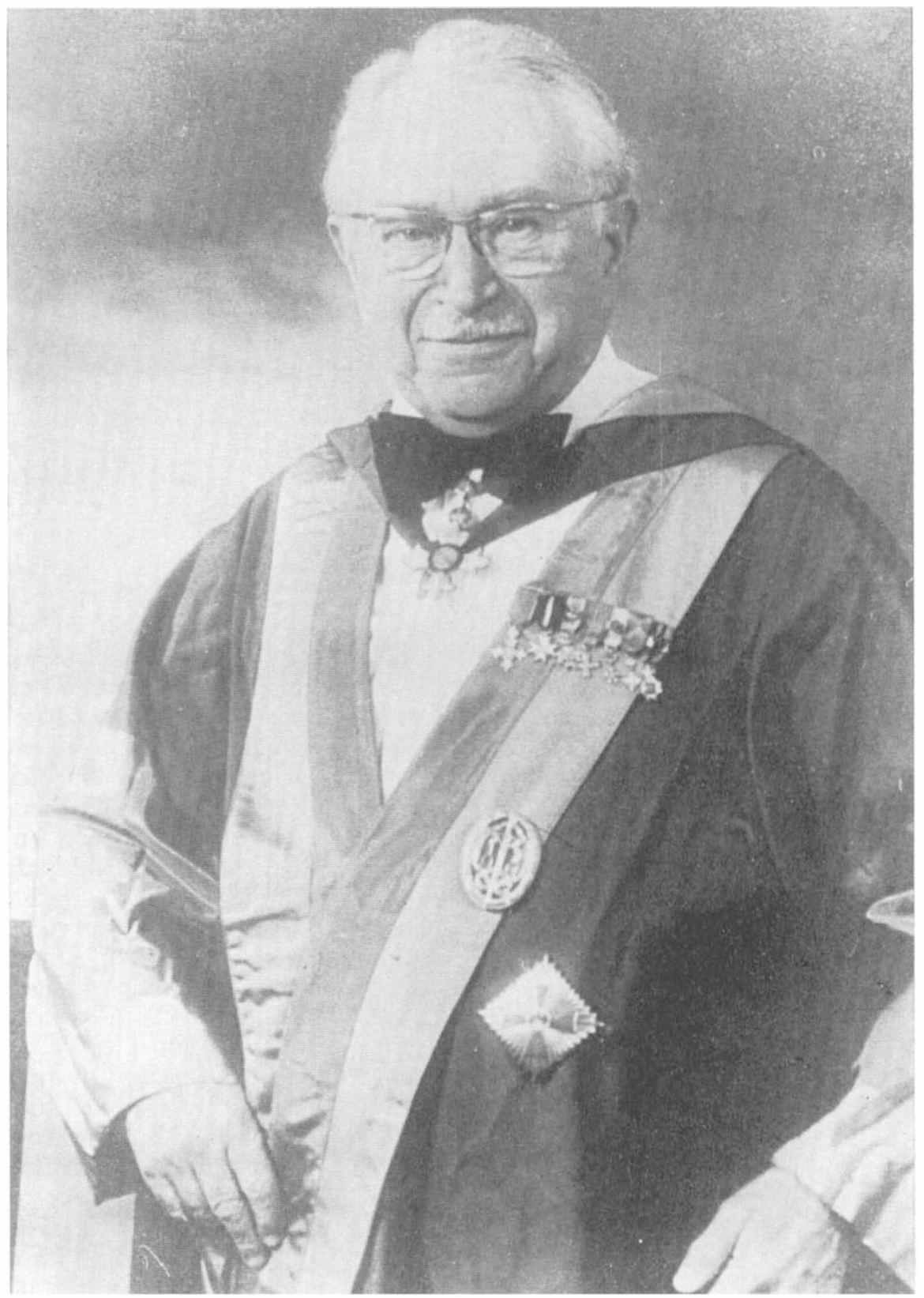




\title{
International Medical Society of Paraplegia First Ludwig Guttmann Memorial Lecture
}

\author{
By Sir George BEDBRooK \\ Department of Orthopaedic Surgery, Royal Perth Rehabilitation Hospital, Selby Street, \\ Shenton Park, 6008, Western Australia
}

\section{'LUDWIG GUTTMANN-MAN OF AN AGE'}

\author{
Friday, 31st fuly 1981. Royal College of Physicians, London
}

As incoming President of the International Medical Society of Paraplegia, now in its 2 Ist year, I rejoice in this unique honour to speak and write of a man most of us in this lecture theatre knew well. As Cassius said, in Shakespeare's fulius Caesar: 'Why, man, he doth bestride the narrow world, like a Colossus'. Almost equally applicable to Ludwig Guttmann might be quoted Marc Antony's praise of Brutus, when he said: 'His life was gentle; and the elements so mix'd up in him, that nature might stand up, and say to all the world- "THIS WAS A MAN!"'

That this Memorial Address should take place in the hall of an ancient bodythe Royal College of Physicians of London, where Ludwig Guttmann had been a proud Fellow since 1962, is more than fitting; while poetic justice has been observed in its delivery by a surgeon. Lord Moynihan said: 'I am a physician doomed to the practice of surgery,' whilst famous orthopaedic surgeon Reginald Watson-Jones said in a Hunterian Oration: 'I am a physician doomed to the practice of medicine'. Ludwig Guttmann was all of these and much more, with his compassion, sense of humour, his discipline, but at times inflexibility. As a Times correspondent on the 20th March I980 said: 'Guttmann had a strong personality and the ability to confront the htghest in the land. He made some enemies but he made more friends and admirers. The success which he achieved and the international acceptance of his philosophy and teaching in the field of rehabilitation were the rewards of an outstanding scientific worker. The principles and the enthusiasm which he instilled into those colleagues who came under his influence will ensure that his work will be carried on by future generations. Reginald Watson-Jones spoke these words of Robert Jones and Hugh Owen Thomas, early founders of orthopaedics, and now I humbly and with deference repeat them of our Founder-President, colleague and friend, Ludwig Guttmann: 'Those whose work cannot die, whose influence lives after them, whose disciples perpetuate and multiply their gifts to humanity, are truly immortal.'

I come from the lands of the Southern Cross, from the home of at least one ancient race, the Australian aboriginal, whose myths and dreams permeate their culture and are transmitted and transplanted to ours. As the first President of the International Society of Paraplegia from the antipodes it is my privilege to portray a man whose dream became a reality within his lifetime. Ludwig Guttmann's dreams in 1919 were more nightmarish as he considered his immediate contact with paraplegia and death. Many dreamers will hardly consider the seemingly impossible, yet Bucy's editorial in Surgical Neurology (I980-page 39I) reminded readers 
that Tennyson had remarked: 'Maybe the wildest dreams are but needful preludes of the truth.' Ludwig Guttmann, like few other men, had a magnificent dream which became a reality. Bucy spoke of Daniel Huston Burnham, creator of Chicago's lakefront, who said: 'Dream no small dreams.' Burley Griffin had a dream for Canberra, the Australian capital, now a reality. Herbert Talbot, second President of our Society, said of Ludwig in 1969: 'Few men see their dream a reality because few have imagination, courage and energy to effect the transmutation of the spirit from a dream to an actuality.'

The Australian aboriginal has many myths and dreams. Most fitting for this time, in this place, is the dream of Wuluwait-the Boatman of the Dead-who paddles a bark canoe to the Island of Purelko, guided by dolphins, where the ordeal for the Spirit, of spears being thrust into his body, transforms that new Spirit into a young, healthy, happy person with great ability to influence others. Truly, Ludwig's spirit will so transform many over the forthcoming years for such a spirit of man is unconquerable, indestructible, incorruptible and unquenchable-immortal. This first memorial oration is therefore a celebration for a spirit, but practically it is about a man, and how he came to be guided into the great pathway he made his road in life. I have recently finished reading the account of The Ghost of Flight $4 O I$ by Fuller, and found it giving strength to this concept of the spirit of man, just as during my quiet thought on this lecture I felt moved by that intangible presence we call by so many names. In the quietness of travel, over many places above the earth, I have realised Ludwig was a 'man of this world, of this globe', not just of one nation and one people but truly of many nations and many people. As the Prime Minister of Israel said of him in I968: 'A great man, of a great nationJewish.'

I am reminded of that great oration in Chapter 3 of Ecclesiastes-a much greater oration to such a spirit as we honour here than I can ever deliver. This chapter relates to the spirit of man. I recently lost another great friend, Cleric Archbishop of Perth, Geoffrey Sambell, who in his final letter to parishioners, knowing he was dying, reminded us of two of the verses of this chapter: verse 2'A time to be born, and a time to die; and a time to plant, and a time to pluck up that which is planted.' And verse 22-'wherefore I perceive that there is nothing better than that a man should rejoice in his own works; for that is his portion: for who shall bring him to see what shall be after him?' I am sure we all agree when I say Ludwig rejoiced in all his works as the spirit moved him.

Whatever our creed, it is transcended by this spirit. You will remember another great chapter in Ezekiel (chapter 37, verse I I): 'Then he said unto me, Son of Man, these bones are the whole house of Israel: behold they say our bones are dried, and our hope is lost: we are cut off for our parts.' Finally, verse I4: 'And shall put my spirit in you, and ye shall live.' This is just what happened for paraplegics and tetraplegics when our Founder-President-a man of men in all seasons and all nations, but of one-accepted, unlike other great pioneers of his day, the total responsibility for the emergence of total care of spinal paralysis and saw his dream fulfilled. Pioneer and man of tenacity, scientist, physician, surgeon, visionary; whose original contact with a paraplegic occurred when but an orderly working in a hospital in a coal-mining area in Silesia, and seeing death come so needlessly, was challenged and stimulated to the result we all know. The journalist-biologist Ardrey indicates such as fundamental to our biological make-up. As Singer said in his essay, published in Next Year in ferusalem: 'The Hitlers, the Mussolinis and the Stalins turn to dust but the works of the spirit are ever imbued with new life,' and went on to say: 'Being a Jew and a man was and is regarded as synonymous.' 
There will be some who challenge this but few to challenge it regarding our colleague. Hospital administrators and orthodox practitioners of the I950s found Ludwig very difficult. He never brooked opposition from such staff, even (it is recorded) to getting a swimming-pool by going direct to royalty! He was selfassured, arrogant, at times scathing in his criticism, but compassionate and an early advocate of team medicine. His battles with orthopaedic surgeons, urologists and neurosurgeons are history and were commonplace. To him, comprehensive units meant total care in all aspects-all important to him as the doctor in charge: hostels, attendant care systems, recreation, sport, employment; in fact he was interested in 'a way of life' for the spinal paralytic.

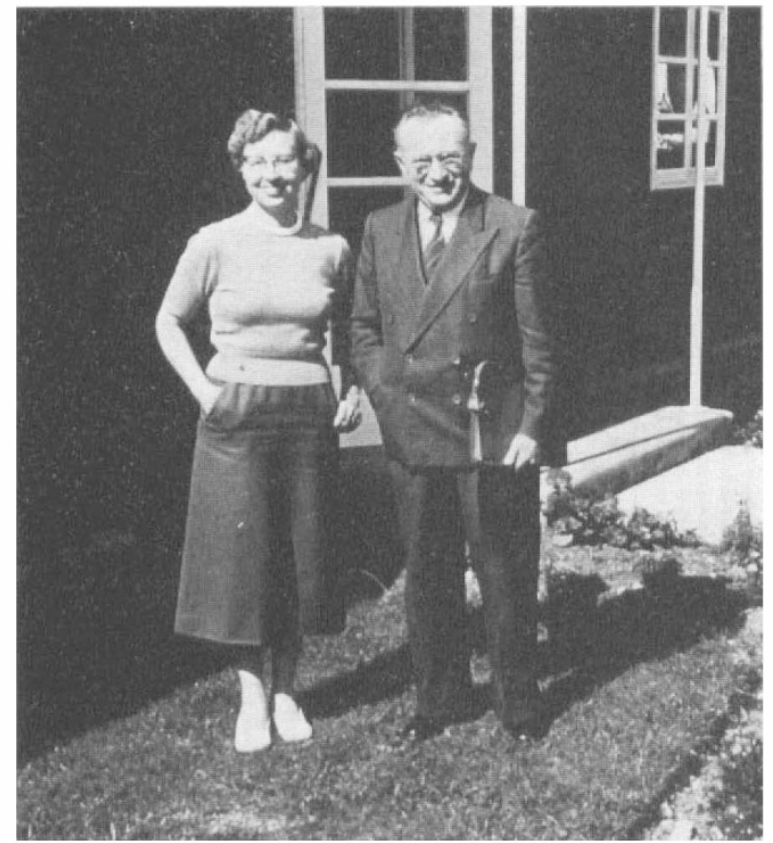

FIG. I

1957, Sir Ludwig Guttman, Miss Joan Scruton.

Some of Ludwig's ideals, now 40 years old, are still too modern for many administrators and doctors-at all levels in government and semi-government bodies. Thus my plea for them to be included in our team effort, and to have more patient and (more importantly) staff contact.

His success in the International Stoke Mandeville Games is a manifestation of a change in attitudes by the community to the paralysed and their acceptance. This of course is a goal for the I98I International Year of Disabled People.

I am reminded at this point of a story of the I957 Games, given to me by Naomi Wing, a long-standing friend of Ludwig's, and repeated I feel certain, many times. Her greatest impression was his insistence that the Games at Stoke Mandeville continue in the pouring rain, to prove to the world that paraplegics could be just as fit, and fitter, than the able-bodied. His driving enthusiasm, matched by the constant driving rain was noteworthy. When I reached 'Stoke' a few days later, I remember the Australians wondering what they had encountered. 
The orchestra of rehabilitation-the old and the new-needs integration in total medical context; whilst as leaders and conductors we must still be, as are conductors of music, experts in areas of involvement. The patient in this orchestration is but a unit of experience. Dropped notes are the complications. Some of the imperfections of the players are spiritual rather than physical. I reiterate what others have already said about great men in many fields: subservient to one aim, an interest in wholeness - an all parts orchestration. It was my privilege to train in medicine in Melbourne, Australia, where great men of the antipodes gave me an awareness of that wholeness of outlook. Sunderland encouraged this with academic work, whilst clinical training with great clinicians like Syme and Hurley in Australia, Seddon and Robertson in this country, extended my outlook further. Finally, I decided to give up peripheral nerve surgery, in which I had undergone extensive training, to come into this area, and went back to pathology as a study for application.

Former eulogies are well known to this audience via The Birthday Volumes of our Journal. I would like to mention a few of the highlights.

Our second President, Herbert Talbot, talked of our general inability and inflexibility after a certain age, yet he indicated our Founder's greatness and vision being manifest when he changed course, almost in his fifth decade. I am reminded that Osler indicated most leaders reach maturity in their fourth decade and it is left to a few to mature later. Ludwig was in that small elite band. He experienced the reality which Talbot brought out in his lecture, that medicine is slow to absorb non-technological advances. Regretfully, as Talbot indicated, the fundamental concept of rehabilitation of spinal paralysis and other disabling conditions, even now in I98I, has not yet become general. 'Man does not live by bread alone'-a fact we all realise only too well in this example of gross motor skeletal impairment.

I said I would talk about Ludwig, the man, who realised the basis of helping people is that they are willing to accept help. His, and our, success or failure as physicians reflects what we are as men. Unfortunately, final responsibility for emergency is not well accepted by medicine as a whole, nor do we, as Talbot said: 'recognise how important we are to each other,' in accepting this challenging final task. We are human too, although we forget this is so of our patients at times, as we exclaim their desire to live in a utopia of joys and no pain, plenty and no hunger, peace and no war; love and no prejudice or hate. Regretfully, ours is not the just society of man so eloquently described by our biologists. Ernst Adler of Jerusalem who helped Ludwig leave Germany in 1939, wrote of his devotion, his sincerity, patience, compassion and his rapport; whilst Ernest Bors spoke of him as a great builder, humorist and dynamic personality. Hodgson and Yau were impressed, as we all were in 1968, with him as a great lecturer when he gave that historical oration 'A New Talent for the Community,' and showed his interest in music, literature and the arts. Al Jousse talked of him as a pioneer amongst many, linking him to Head and Riddoch; whilst Botterell and Munro, the other two of a great trinity spread over three nations, indicated his leadership, being the first trained person in paraplegia. His greatest contributions-this Society, its Journal, the comprehensive unit, and the International Stoke Mandeville Games, are their own eulogy.

I am reminded of an editorial in the Australian Medical Fournal years ago, discussing leadership. The writer indicated how often medicine not only produced leaders but more often buried them by divisions and jealousies: such leadership, as emerged at 'Stoke' was achieved with much difficulty.

The list of contributors to the Birthday Volumes is a long one indeed. Many spoke of his contagious spirit, of him becoming a pilgrim, and how the directorship 
of the Jewish Hospital in Breslau (now Wroclaw) demanded courage, energy, hardship and certainly trained him for the future as a great adventurer whose whole life after I940 was to further the International Year of Disabled People aim in Australia, by breaking down barriers. Charles MacMillan talked of a great octogenarian, flowering like the palm tree in old age-'Time that doth all things else impair, still make them flourish strong and fair.' Finally, I remind you of McSweeney, likening him to that great Jew, Saul of Tarsus, whose name as St Paul became a byword for all the world to hear with his love of one's fellow man, or in Hebrew-'Ba-al G'zadakah'. Just as St Paul travelled, 'giving respectability and status to the poor and the peculiar, the sick or disabled, the old and the orphaned, the widowed, the blind and the variegated victims of fate', so did Ludwig. There is no direct word for charity in Hebrew-the closest is 'tsedakah' which correctly means righteousness, or a duty. I suspect, like many other Jews, Ludwig felt a sacred obligation to the 'tsedakah' (duty) he saw in the disabled: a tradition ingrained in the years of the Talmud and 2000 year settlement of Europe. In this context, it may be remembered that Jewish communities often had a free hotel attached to the synagogue for itinerants, wayfarers and the handicapped.

The world's eulogies rolled on-how can I hope to say more, yet in two ways at least, there is more to say. How did being Jewish influence and affect him as a man, and secondly, what was his influence in the antipodes?

The account by Cosbie Ross and Harris in our fournal leaves little to be said of Ludwig's early days in Silesia. No doubt his personal biography will make interesting reading. Studying the turbulent history of Silesia before and during his early days one can see how this moulded not only his first I 9 years, when he lived at Koenigshütte, but it affected his attitudes and his personal territory for the rest of his life. Silesia has always been a disputed area of Europe. From A.D. I000 there has always been a Polish bishopric at Wroclaw. The eleventh century saw early division into two duchies whilst, by the early fifteenth century, division and re-division had occurred. Ethnically German settlers started to arrive and by the end of the thirteenth century Wroclaw became Breslau. The powerful Kings of Bohemia influenced but did not conquer the area. In 1526 the Hapsburgs took control and by the seventeenth/eighteenth century, Breslau was one of the largest cities in Europe. Soon the Prussian Empire wrested its control, turning the area of Ludwig's birth and that of his innkeeper/distiller parents' sojourn into turmoil amidst beauty. Whilst Lower Silesia was dominantly German, Upper Silesia was mixed Polish/German, with less than 5 per cent Jewish and the rest Protestant and Catholic. Adjacent European and Russian ghettos influenced his predecessors whilst the end of the First World War brought further turmoil to him as he emerged into manhood. Ludwig studied at the Medical School in Freiburg, graduating in 1923. His first medical assignment was at Krolenska Hüta in Silesia. He then spent 2 years at the State Mental Hospital Friedrischberg in Hamburg, as a neurologist/neurosurgeon. (Registration lists for 1928 record his name.) The influence of his time with Foerster, as he moved from Freiburg, Hamburg and Breslau, moulded him, while the influence of two cultures helped him when after a Readership in Neurology at the University of Breslau, he became Director of the Jewish Hospital. Foerster's cautious approach to surgical technique laid its mantle upon him. In retrospect, his training and culture led him into a neglected area of medicine, leaving him self-assured, bold, arrogant and at times impatient with those whose knowledge did not meet with his, although amidst it all his very Jewish tradition manifested compassion and charity. Just a few days ago, Wroclaw (then Breslau) celebrated its Flower Day, a festival Ludwig must have known well: this 
ancient city of fine gothic, secular architecture, and a baroque-style university, gave him a sense of beauty which he never lost.

The turbulence of race, geography and his training made him what he was when I first met him 30 years ago, on a wet and foggy morning in January I95I-a fighter ready to defend his knowledge and intolerant of orthodox methods. As T. B. S. Dick said, he found him an authoritative organiser when he was advised to view the then unorthodox methods with flexibility. Kipling's poem of Six Serving Men may have been unknown to him-'Their names are What? and Why? and When? and How? and Where? and Who?'-but it is so apt to those attributes or attitudes who served inside this great man.

The emancipation of European Jewry by the middle of the eighteenth century led to very great advances in almost every area of knowledge and culture. There was a great shift of Jews into commerce and professions. In our Founder, as I came to know him better, and particularly as I prepared this celebration to his memory, I found many attributes and attitudes in one man-great Jew, great man, as I have already mentioned. Being both has always been synonymous in Jewish tradition. While the idea of compassion was foreign to Greeks and Romans, to Jews in captivity, in ghettos, all round the European world, it was part of their life: thus the mendicant 'Schnorrer' was accepted. The Schnorrer expected his due as a self-appointed agent of Jehovah. He enforced on all the requirement of 'mitzvah' (good deed). Looking back, I can catch a glimpse of this character in our FounderPresident, while I can more easily see the basic 'tsedakah' or charity, or encouraging self-help, as his sacred duty, not only as a physician but as a Jew. In another way, 'tsedakah' can also mean 'helping someone to help himself' by giving work, or financing an enterprise; helping a man secretly. Even the Jewish passion for learning and their veneration of scholars and sages were subordinate to the 'tsedakah'. It is better to help a cripple than help a scholar' is a Jewish saying. The mendicant 'Schnorrer' took advantage of this in a peculiar but dignified way.

After 2000 years in ghettos the emancipated Jew carried with him powerful and characteristic burdens of inheritance which influenced the patterns of his advance: bold yet cautious, as they made inroads into life; arrogant yet humble, in their dealings with others; full of knowledge but apparently ignorant, voluble yet secretive, independent yet within a social group, stimulated yet apathetic, secure yet insecure. These traditions were all present in this man of men who showed the great contrasts of homo sapiens so well.

Poland was the last 'fortress of the Talmudic Jew'-ruled by the Messianic hopes for the future with little worldliness. In the second half of the nineteenth century there was a great Jewish breaking-out in Europe-Marx, Freud, Rothschild, Lévi-Strauss and more recently, Spitz, Mosbacher-to name a few. Many graduated in medicine in the I880s in Scotland, then emigrated to America. The Jews remaining in Europe were traders-liquor tradesmen, drapers, shopkeepers, marginal men, hoteliers (like Ludwig's parents). Some of his relatives were exterminated by the Nazis at the infamous Brzaezenka Camp. They had to, and were able to, change their attitudes and positions quickly to survive. They were entrepreneurial in business-getting things done. Ludwig was certainly in that group. Like many others, he was the product of a special period of Jewish history, whose revolutionaries regarded themselves as citizens of the world. The motives causing them to be radical are very complex but one decisive force was the specific Jewish urge for justice. Many rejected their Jewishness, to acclaim German, French, British, Russian status, as though this would give them peace. Our Founder-President, I believe, was one of a great group of 'Meta Rabbis' or 
'Tsadikim' whose influence in art, literature, philosophy, science, business, mathematics, sport, in the century I 850 to I950 cannot be discounted in our world. Conceivably it was the release from Jewish religiosity and the irritable meeting of emancipated Jew and Gentile that released the creative force that was showered on the known world. Meta Rabbis they remained, despite personal eminence and creative talents-'outsiders' almost, guests in their own skins due to their Jewish past and unorthodox philosophy. There is a saying-'Of that of which one cannot speak one must be silent.' Ludwig joined a group with a Jewish alternative-'Of that of which one cannot speak one must sing.' Truly one of Singer's Meta Rabbis. The West gave Jews freedom of religion, freedom of education, economic opportunity, and they repaid with industry, science, medicine, art, entertainment and sport. Karl Franzos said: 'Every country has the Jews it deserves.'

Like so many before him, Jew and Gentile, he restarted at the bottom of his new territory. As an individualist he drove forward with iron discipline, both for himself and for those around him, but with compassion, and later as success was assured, tempered with humour and kindly thought. I am reminded of a line from Verdi's famous opera: 'Go thought on wings.' The unorthodox, practical activities conceived by Guttmann and Munro, almost simultaneously and without knowledge of one another in the early I940s were indeed 'Spread with wings.' His progress in this country and later Europe and America was not smooth and his course was always turbulent. His battles in medicine are historic, even until a year ago. His early acceptance of team medicine set him apart. Orthodox medicine has regularly had such spirits to contend with, both inside and outside its territory. Just two incidents are worth recording. Joseph Griffith, a renowned hospital administrator of this country and Australia, told me he remembers a dinner-meeting of all London Medical School Deans at St George's when, after a complimentary speech by his host, Ludwig quickly upbraided the London Teaching Hospitals, not one of which had availed themselves of his nursing course in paraplegia, despite his oft-renewed offers over many years. By contrast, Australian and New Zealand hospitals, even then, were regularly sending experienced nurses for further training. The second incident related to his quick and decisive action, supporting a paraplegic resident at a hostel who was concerned at the lack of hygiene and care in catheter changes, and how he quickly caused disciplinary action to be taken.

My first contact came, as I have already mentioned, when I visited 'Stoke' to follow-up a case I had cared for in Surrey. I was quickly made welcome but his ward round was almost vitriolic in its conduct, both to staff and patients; yet there was a confidence expressed in the patients' answers not before seen. They were, as in other fields of medicine, at last the star of the play, receiving benefit from many resources; albeit he was cautious of some, including social workers. He imparted that 'mix' we all came to know and admire-bold yet cautious, angry yet kindly. He was a teacher of excellence, a philosopher-a Meta Rabbi.

Byron Kakulas, an eminent Australian neuropathologist, and a good friend of us both, recalled being invited by Glenn Reynolds to travel by car with Ludwig along the west coast of America from San Diego to San Jose, a memory he treasures for he witnessed another side or facet of this extraordinary man whose spirit we honour. Ludwig provided a continuous fountain of entertainment relating to anecdotes of German neuropathologists and tales of eluding Nazi intrigue, whilst his ebullient personality was an instant pleasure and delight. (I also had this experience myself when he visited Perth in 1978.) Byron was very impressed with his knowledge of neuropathology. As the Big Sur slipped past, his wit, intelligence and language revealed a kaleidoscope not experienced by his companions before. 
His stories were many, like the one about the schizophrenic at a swimming-pool in which there was no water, and when confronted with this fact promptly replied: 'that's all right, I cannot swim anyway!' Or the story of the Englishman, Frenchman, German and Russian at the European Economic Community Academy Meeting, when asked to write an essay on the elephant. The Englishman naturally wrote three pages on big-game hunting, the Frenchman discoursed for five pages on l'amour d'elephante, whilst the German wrote I30 pages on the introduction to the elephant, and the Russian gave his contribution in two words-no elephant! The facets of this man of men, citizen of the world, German but Jewish, constantly change.

And so I come to a geographical area, the antipodes, where even there the Jewish influence was great, being far removed from Europe and not so concentrated. Nevertheless, those distant lands are renowned for great pioneers, and where there is a story not yet told, of another Jew-Max Herz, also a 'break-out'-who was responsible for bringing European orthopaedics, amidst similar disharmony and conflict, into Australia and New Zealand.

This might be an ideal opportunity to introduce another old friend of Ludwig's - Sir Zelman Cowen, distinguished jurist, Professor of Law, Rhodes Scholar and

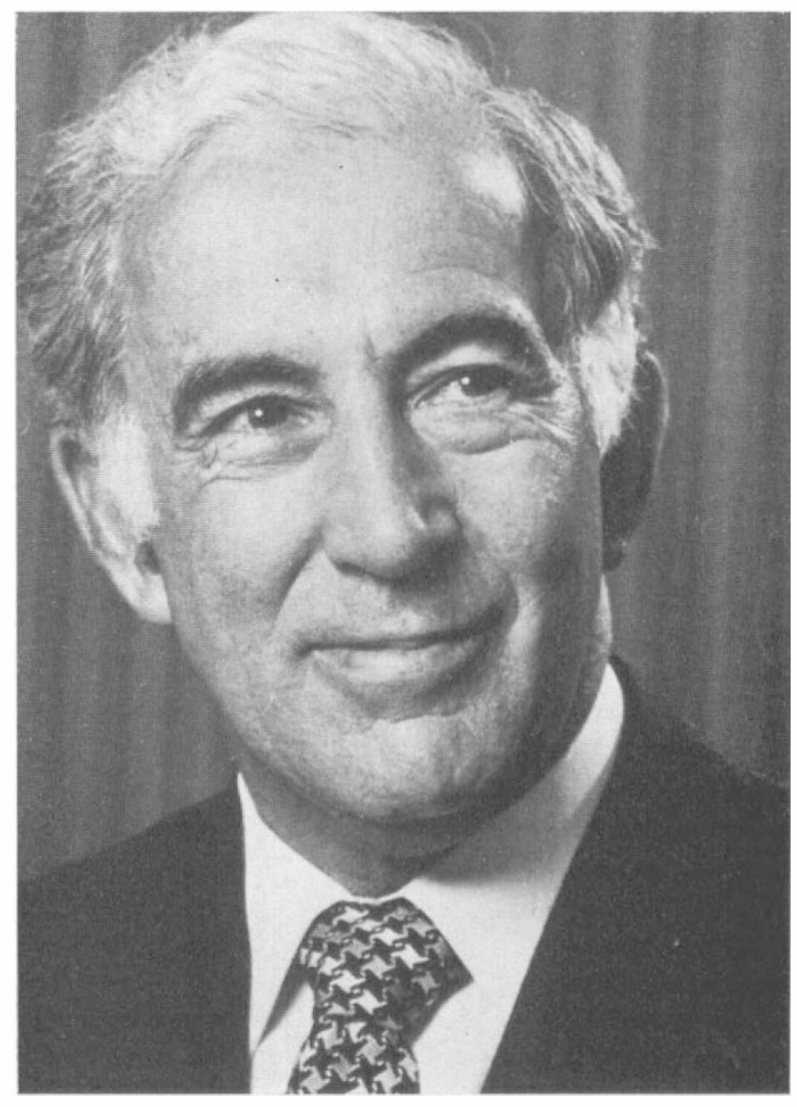

FIG. 2a

His Excellency, Sir Zelman Cowen, Governor General of Australia, friend of Ludwig Guttman, I948. 
now Governor-General of Australia. Sir Zelman remembers some of the probiems Ludwig encountered in the late I940s, and of his family sharing food parcels with Ludwig's when they were both living in Oxford.

Ludwig travelled very extensively indeed, and derived great pleasure from his tours-a Meta Rabbi: authoritative, knowledgeable, always sure and usually right, friendly but arrogant. We saw this man five times on his visits between I 957 and 1978. In each capital of Australia and New Zealand where there is a spinal unit his acceptance was assured but his attitudes changed markedly with the medical progress and the chaos he found.

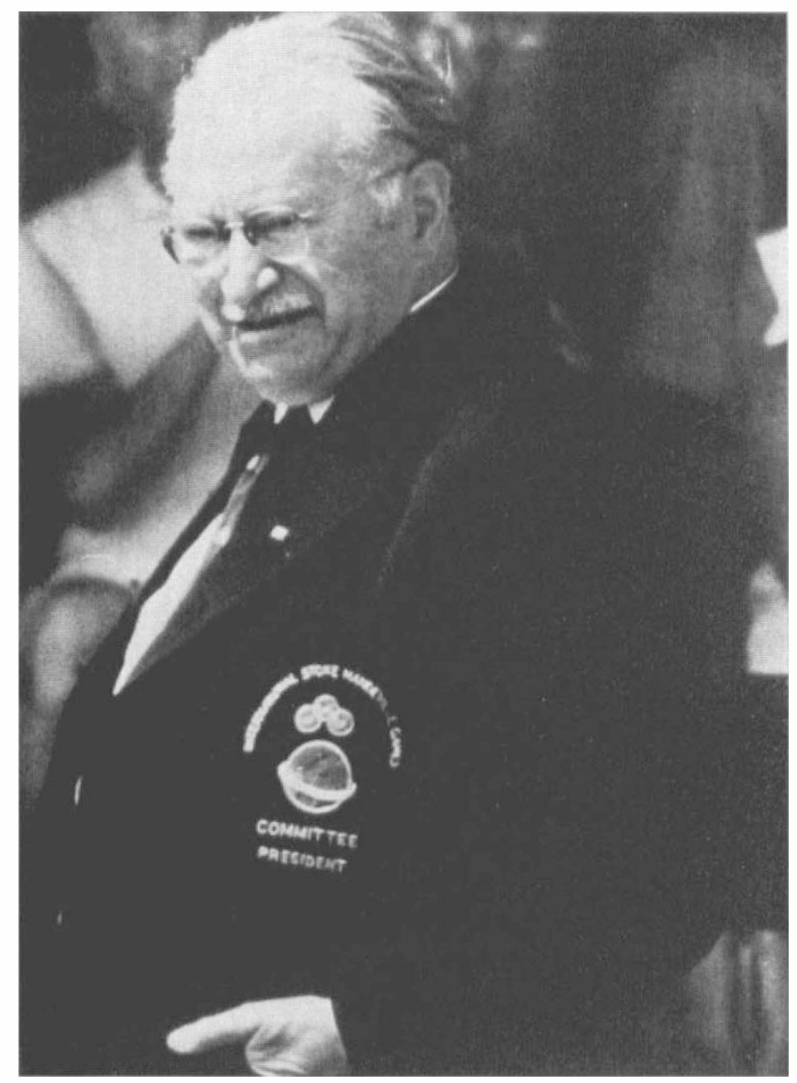

Just recently in New Zealand, I discovered that the father of an orthopaedic colleague, Robin Higgs (now practising in Sydney) was one of Ludwig's first civilian patients in I945. Unfortunately he was terminal but Ludwig is remembered with love by the family.

His first visit to Australia was sponsored by the Nuffield Foundation and organised by Don Duffy, a urologist and Naomi Wing, both of Melbourne, and Rex Money, a neurosurgeon, of Sydney. On that visit Ludwig met Naomi, another great pioneer of rehabilitation, who became a life-long friend. I am told by her that he almost caused a riot at one hospital, bringing considerable impact to the hospital and the public, as his tour organisers hoped. Lionel Watts, President of the Australian Council for Rehabilitation of the Disabled, severely handicapped by polio, remembers Ludwig's I 957 visit to the Royal North Shore Hospital in Sydney. 
Lying in an orthopaedic ward, opposite an anaemic, decubiti covered, urinary infected patient, Frank Windsor, he remembers the complete pantomime that erupted when Ludwig saw that ill and debilitated man. The language flowed, the gestures were eloquent and resulted in regular turns, correction of anaemia and good health. This man is still alive and well, his life saved by our FounderPresident. There must be many similar examples, in many countries. In this hutted ward, Lionel remembers the autocratic authority of the ward sister and the way his paraplegic ward mates tricked her with their alcohol consumption hidden in Lionel's locker as he was quite immobilised and therefore above suspicion. Rex

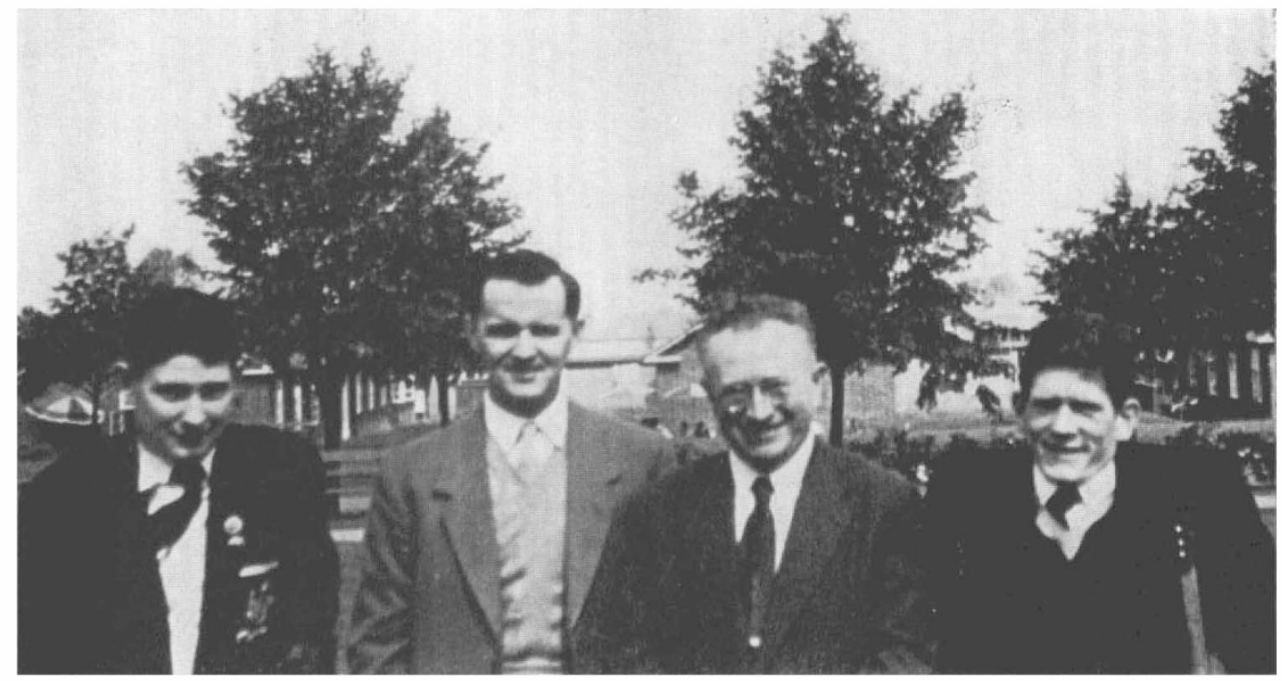

FIG. 3

1957, Alan, George M. Bedbrook, Ludwig Guttman, W. Mather Brown.

Money has sent me the documents of that visit, as they still exist, including his itinerary of lectures and verbal reports. This report was scathing indeed. His attack on the then Minister was and is a condemnation of the then spasmodic, dispersed, inadequate care of paraplegics and made newspaper headlines. His public lectures on the use of prostigmine in sexual difficulties caused a run on that drug by those seeking to overcome impotence and failing sexuality.

Tragically, I believe, paraplegics were to suffer by his angry dismay which some believe caused planning and execution of comprehensive units to be delayed or deferred. He was openly sympathetic and helpful to those doctors attempting to introduce his methods but critical if they were not up to date. His return visit in I 962 found some progress but priorities were to remain low for another Io years. Little progress had been made in the 5 years since his visit and little interest was shown by both the authorities and the profession. His final visits were happy ones for all as he found two comprehensive units serving Sydney and New South Wales well.

In Melbourne he was 'Poppa' (as he was affectionately named) with a father/ son relationship in the hospital; then as almost a grandfather. There, he did not experience the brashness of Sydney. David Burke recalls Ludwig's second visit to Melbourne well. A spinal unit had opened there in 1956 but his first visit in 1957 
resulted in the Austin Hospital Spinal Injuries Unit being firmly established at Heidelberg. Due to difficulties in obtaining staff the first Director, David Cheshire, was not in firm control until I959. The unit then developed rapidly. Undoubtedly it was the 1962 visit which stimulated David Burke to specialise in this field, and he remembers how Ludwig upset two orthopaedic surgeons by using his classical repetitive remark, asking them to show comparable results! 'By their deeds you shall know them' has been well said. His visits to Melbourne in I957, I962, I968, I974, I976 and I978 were inspiring to all. He loved meeting old friends and patients and had a habit of 'staying on'. His stimulus to junior medicos was infectious, particularly on better acquaintance.

In Adelaide, South Australia, my colleagues felt he tolerated them as errant and wayward children. They, in turn, rather enjoyed their waywardness with great cordiality. Brian Cornish's wife well remembers how Ludwig's visit was enjoyed by their family, and how a formal meal in his honour was turned into chaos by the children who were greatly attracted by his infectious company.

South Australia has a significant association as early settlers to the colony came from Silesia to avoid persecution for their beliefs as Lutherans.

In Brisbane, Ludwig's first visit in 1957 saw a clash with administrators who regarded paraplegics as drunken outcasts. They were quickly told that if he had been treated similarly to those paraplegics, he too would be a drunkard, and he became so angry he left them standing quite speechless. I well remember him talking of this incident when he later came to Perth. Queensland, our maverick state, now has a well-organised service, yet administrators are still loth to give support.

At this point I will digress to Ludwig's influence and experiences in New Zealand before elaborating on my personal territory-Western Australia.

His impact on Auckland and Christchurch came at a later time than Australia. He visited New Zealand in I97I, and again in 1974 for the final Commonwealth Paraplegic Games, and was frustrated by the indecisiveness and refusal by administrators to see that action was necessary. Civil Service time was not Ludwig's time! His aggression towards administrators was very natural and characteristic. Ross Nicholson sent me a copy of Ludwig's letter to him of the 29th April I97I, written after he had returned to the United Kingdom. He expressed his concern about the Auckland Hospital Board's reluctance in I97I to implement their I963 plan. They saw paraplegics as the ninth priority on their list and indicated 1980 could or would be the date of implementation. His letter revealed his compassion for he was anxious about New Zealand's paraplegics; and outlined the depth and scope of his discussions with the Health Minister of New Zealand, even to despairing that each paraplegic was expected to purchase his own wheelchair. Just recently, Ross recalled the journey he made from the beautiful Bay of Islands to Dunedin to discuss the unit with Ludwig in 1974 and how he received an urgent call to telephone Ludwig regarding a donor for the unit after he had returned home. Fortunately by then the government had appropriated money so finance was not, in 1974, the paramount concern. The new Auckland unit opened in 1976, due to hard work by Ross Nicholson and others, as well as the pressure by Ludwig during his 1974 visit. Reverting to his letter of the 29th April I97I ; Ludwig went on to say how gratifying it was to find the Christchurch Hospital Board setting a number one priority for the Burwood Paraplegic Unit which was opened in 1977, a small unit having been in existence since 1963. Both Alan Bean from Christchurch and Brian Otto from Auckland were given the opportunity to have spinal injury experience and training in Perth and other Australian centres. 
On the other hand, in Perth (across the vast Nullarbor Plain) on his half-dozen visits he encountered a different spirit for here was a group who could claim, via Leslie Le Souef (Consultant Plastic Surgeon) to be his oldest Australian medical contact, and so a place where his teachings had matured longest. On his first visit he set about disciplining, in his usual fashion, those who disagreed with his methods, asking them to produce similar results. The setting up of a spinal unit in 1954 by the co-operative action of an orthopaedic surgeon, a neurosurgeon, a urologist, a plastic surgeon and an enlightened administrator is a fact of history. Wherever and whenever I met him, Ludwig always asked after the original team. Eric Kyle, the urologist in this historic group, is still active.

Leslie Le Souef met Ludwig in April 1945, soon after his release from a 4-year internment in German prison camps. As the Senior Medical Officer of the Australians interned, his own rehabilitation included being advised by Sir Thomas Home Sellers to visit Stoke Mandeville from close-by Harefield to see the revolutionary care being undertaken there. Thus he became Ludwig's first Australian medical friend (although Sir Zelman Cowen may have been his first Australian friend). Whenever in Perth, Ludwig always visited Leslie's home and was a great favourite of Mrs Le Souef and her friends.

Leslie Le Souef's report to the Western Australian Government listed the reduction of complications as being his greatest impression of his first contact. Ludwig gave him a full account of the gross depression, apathy and feeling of hopelessness that had to be dispersed. He regarded depression as the most major complication of all, as it continues to be today. Leslie Le Souef returned to Western Australia via North America where he visited Botterell in Canada and Munro in Boston. The latter was then reporting on 48 cases treated over 20 years with improved results. Munro can be regarded as the catalyst to improved care in North America.

In I948, as President of the British Medical Association in Western Australia, Leslie Le Souef gave a Presidential Address on Rehabilitation which impressed and stimulated Dr Oswald Corr, then Superintendent of the Military (later Repatriation) Hospital in Perth. In the repatriation ward of the Royal Perth Hospital, and later at the Hollywood Repatriation Hospital, the first attempt at better care for paraplegics in Australia was made when Dr Corr collected them all together. This doctor-administrator corresponded with Ludwig and visited Botterell and Munro. Sixteen cases were treated in the embryo unit which closed in 1952 as official approval was refused to carry on with civilian cases. Between I 948 and 1952 Oswald Corr advocated multidisciplinary assistance in management, travelling throughout Australia in his holidays lecturing on our Founder-President's methods. He was very greatly influenced by a couple of early articles by Ludwig in physiotherapy journals. A film was made and used widely, but without much influence in the eastern states. Oswald Corr was fortunate in having considerable assistance from a physiotherapist, Miss Pender, and from the vocational workshop for service personnel at Hollywood Repatriation Hospital.

I remember it was a hot and dry summer in Perth, in 1954, which marked the beginning of our present service; and when I was literally 'instructed' by our then senior orthopaedic surgeon, Alex Dawkins, to be co-ordinator. It was at that stage I met Leslie Le Souef, who recently recounted for me these very early impressions. With the great co-operation of those already mentioned, the service was accomplished without jealousies: with amity, the spirit of Ludwig Guttmann, sown in Leslie Le Souef and Oswald Corr, became manifest. By the 6th June 1954, the Royal Perth Hospital had a well-established service. It was on this day a grim motor vehicle 
accident occurred (typical of the holocaust still besetting Australia) leaving two young girls paraplegic: one with complete paraplegia at T.4 and the other complete at T.II/I2. This was a day we remember well.

Ludwig's visits to us were always interesting. He always brought wisdom with his seemingly inexhaustible knowledge of the spinal cord. His research and investigations were eagerly discussed for we had no fundamental difference of opinion, although at times he must have realised our territorial rights and what was right and proper in the United Kingdom was not so in our southern continent. His last visit in 1978 coincided with the 2 Ist birthday of our Paraplegic-Quadriplegic Association in Western Australia and the completion of the new Activity Therapy Centre which he was asked to officially open. The other reason for his visit was to participate in a Seminar on Rehabilitation at the Royal Perth Rehabilitation Hospital where he delivered the paper 'Health Deviations in Paraplegia', a classic now, published in full in our Journal. He insisted on entering the lecture hall on Leslie Le Souef's arm, a symbol of close friendship over 33 years. His visit was indeed a happy one when he was able to enjoy a sojourn with Air Chief Marshal Sir Wallace Kyle and Lady Kyle, old friends from his R.A.F. days, who were then the Vice-Regal Representatives in Western Australia. We saw him off with happy memories tinged with sadness-great citizen of this world, great Meta Rabbi.

A year later in Mulhouse, I sat with him at dinner and he expressed his delight of his antipodean visits. We discussed prevention which he felt needed all the effort of this now mature Society of ours.

And so he passed from my sight but his memory lives on in the great south lands, from where I come-the Land of the Dream Time, the Boatman of the Dead; and many other dreams of an ancient race.

Before I indicate briefly, and finally, how Ludwig's life points to the future, let me pause for a moment and ask what were his great advances?

comprehensive units, including training

reduction of complications

recreation-the Stoke Mandeville Games and the International Society of Sport for the Disabled

the International Medical Society of Paraplegia

the Journal of Paraplegia

rehabilitation of spinal cord injuries at world level

Ludwig was a 'Mender of the Maimed' in Sir Arthur Keith's great tradition. I simply recall for you the statements made by so many, reminding you what Carlyle said: 'A well-written life is almost as rare as a well-spent one.' His life, I hope, will be regarded as such. Many phrases and character expressions have been used to record his attributes and achievements-great octogenarian, physician and neurologist scientist; wonderful enthusiast, humanitarian, visionary and friend; steadfast conservatist yet abounding in unorthodox methods to build and organise; great and dynamic personality, mixing humour with discipline; a lecturer unsurpassed in his pioneering - a leader of men with a fertile imagination and skill. His mountaineering prowess led to adventures in uncharted and neglected areas where his skill became legend, showing his individuality. His courage and tenacity as he was a pilgrim traveller over these seas led him to quieter harbours where his contagious spirit could show the depth of his compassion for all disabled.

When we study these qualities thoughtfully, we are no longer left to wonder why he had the capacity for finding hidden talents in the disabled whose care he revolutionised. Thus was uncovered for our communities a hidden spark that even 
after disability will make a human being great. Two examples come to my mind: one, blind, with bilateral hip arthritis and cauda equina paraplegia, with causalgia, who conducted a flourishing business and found time to give to developing schools for children. The other an aboriginal who became a great painter. Our respective countries have seen the parable of the faithful servant and his talents repeated time and time again because of our pioneer Founder-President.

To what would he have turned his attention next, and what would he have given priority as the 'eighties stretch out? My opinion is prevention would have been next. I believe in the future we must concentrate on prevention of traumatic paraplegia for the costs are so burdensome, not just in care but in the non-monetary areas: intangible but real. By education we must attempt primary prevention. Our attempts to date have had little effect-posters, films, school programmes, voluntary groups-used in at least two areas already in accident prevention. Seat belts in Australia have had some effect on the multifactorial problem. Just recently, the New Zealand Rugby Council changed their rules to reduce spinal injuries. We must not be baulked by the immensity of the problem. Ludwig Guttmann, Donald Munro and Harry Botterell could easily have been overwhelmed by the immensity of the problem. At this moment, the I98I International Year of/for Disabled Persons is bringing the mammoth overall problem of prevention to the attention of our communities. We are, I regret to say, not experiencing a balance in the effective use of our resources. Too many resources seem to be going to acute resuscitative care. Prevention and restoration-inevitable twinsare not receiving their share of finance available. If, as Osler indicated, 'medicine is catholic' then prevention must be given more emphasis and more finance and time.

So I come to a few final thoughts in the story of our great heritage with a challenge for the future. What a narrative of courage, endeavour, enthusiasm, and finally success, it has been as the barriers were swept aside and the hurdles conquered, the obstructions bypassed. In man, Ludwig had infinite faith. We have been left the challenge to further reduce, not just the disability of spinal paralysis but the chance of it even occurring. His whole career and life points to the necessity of prevention despite the need for better continuing care. I wonder what history will record of this extraordinary man we honour today? Patients will recall him personally for only a short period of time, most will not even realise how much he gave to medicine, and most will take for granted the benefits that are now theirs - that is, simply being human. In fact, the greatest benefit given to them by our pioneer is that for the most part they will be just unequal individuals, as you and I are unequal, in I hope a just society, sharing independence with aggressive behaviour, being selfish but stimulated: in fact, coping with life.

We all recognise that the whole of life is a continuance of the past, present and future so for all time there will be three periods in the care of spinal paralyticspre-Guttmann, the Guttmann era (now rapidly closing) and the post-Guttmann era-the future. Tuesday, the I8th March I980 proved a day when the Talbot/ Guttmann's era drew to a close: a date to be marked as an end or just a beginning. Thus we enter a time of consolidation, a post-pioneer period-the post-Guttmann era. One of the great pioneers of paraplegia is still with us-Harry Botterell of Canada. The other, Donald Munro, we remember with gratitude for his inspiration in the North American Continent.

The International Medical Society of Paraplegia must be recognised and maintained as the expert body throughout the world. It can only be so if we show our expertise, not just in one area, and certainly not if we support the dichotomy, the $20 / \mathrm{I}-\mathrm{B}$ 
piecemeal methods, still practised widely. Our Society must speak out, as did our Founder-President, and be accounted for by governments, instrumentalities, hospitals, societies - as the combined voice of authority.

The spirit of our Founder-President lives on, not only in Purelko, the Australian aboriginal heaven, but in its influence on those who will come afterunquenchable, unconquerable, guiding the destinies perhaps of those who 'labour in this vineyard'.

My Address is over-to a great Jew, a great citizen of our world, great colleague and friend. So the hand of time has written, and having written moves on. T. W. Brown said in his Religio Medici: 'Thus we are men and we know not, there is something in us that can be without us and will be after.' This could truthfully be said of Ludwig Guttmann-

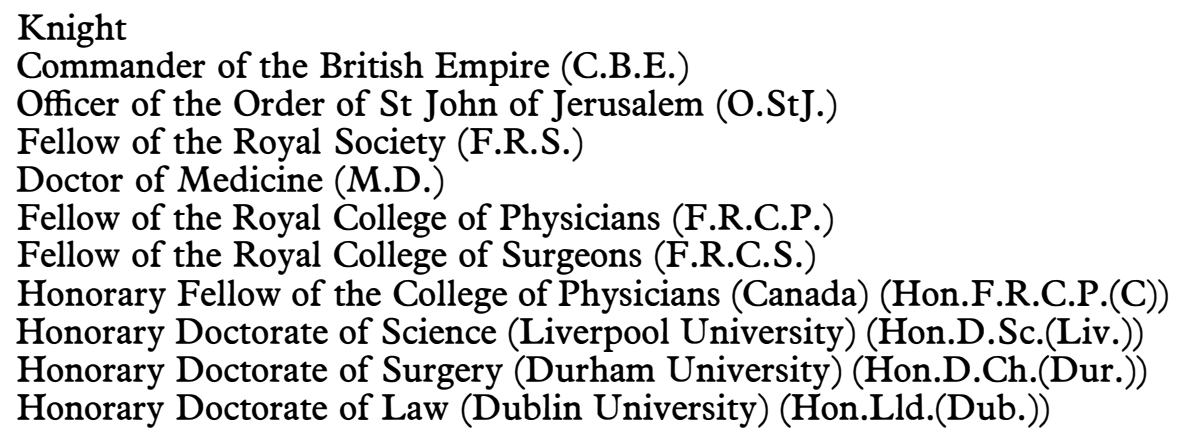

\section{Our Founder}

The Author acknowledges help given by many whose memory of Ludwig Guttmann's achievements and contacts contributed much material, including:
O. R. Nicholson, O.B.E. (New Zealand)
D. Burke (Melbourne)
J. Grant, O.B.E. (Sydney)
B. Cornish (Adelaide)
J. Yeo (Sydney)
L. LeSouef, O.B.E. (Perth)
N. Wing, C.B.E. (Sydney)
E. Kyle (Perth)

\section{REFERENCES}

The BIBle-Ecclesiastes: Chapter 3, verses 2 and 23; Ezekiel: Chapter 37, verses I, I I and I4. Birthday Volumes. Paraplegia, 7 (1969), I 43-I 78, 17 (1979), I-I38. Longman, Harlow. Bucy, P. C. (1980). Dreams. Fournal of Surgical Neurology, I, 39I.

Clarke, J. (1976). Dr Max Herz-Surgeon. Alternative Publishing Co-operative Limited, Sydney.

Cosbie Ross, J. and Harris, P. (1980). Tribute to Sir Ludwig Guttmann. Paraplegia, I8, I 53-I 56.

Fuller, J. G. The Ghost of Flight 40r. Corgi Books.

GutTmanN, SiR Ludwig. Rehabilitation: New Talent for the Community. Proceedings, 4th Pacific Rehabilitation Conference of the International Society for Rehabilitation of the Disabled (September I-7, I968), p. 7.

GutTMAnN, SiR Ludwig (1976). Spinal Cord Injuries: Comprehensive Management and Research. Blackwell Scientific Publications Ltd., Oxford, England.

GutTMANN, SIR Ludwig. On Health Deviation and Rehabilitation in Spinal Paraplegia and Tetraplegia-The Harben Lecture, 1976. The Royal Institute of Public Health and Hygiene, November 1976. Published in Community Health, 8, 4. Reprinted in Paraplegia, 17 (1979), 96. 
GutTMann, SIR Ludwig (1977). Textbook of Sport for the Disabled. University of Queensland Press, St Lucia, Queensland.

MountFord, C. P. and Roberts, A. (1969). The Dreamtime (Australian Aboriginal Myths). Rigby Limited, Sydney.

Talbot, H. S. (I969). Rehabilitation in a changing world. Paraplegia, September, p. I46. VILliERS, D. (Editor) (1975). Next Year in Ferusalem. Harrap, London.

\section{NOTES}

I. Yiddish, the Language of Exile-Isaac Bashevis Singer (p. 55).

2. Some 'Meta Rabbis'-George Steiner (p. 64).

3. The Schnorrer: Piety and Paradox-Leo Rosten (p. I2 I). 